\title{
Enantioselective Conjugate Addition of a Lithium Ester Enolate Catalyzed by Chiral Lithium Amides
}

Nicolas Duguet, ${ }^{\dagger}$ Anne Harrison-Marchand, ${ }^{\dagger}$ Jacques Maddaluno ${ }^{\dagger, *}$ and Kiyoshi Tomioka $^{\ddagger, *}$

${ }^{\dagger}$ Laboratoire des Fonctions Azotées \& Oxygénées Complexes de l'IRCOF, UMR CNRS 6014, Université et INSA de Rouen, 76821 Mont Saint-Aignan Cedex, France;

${ }^{\ddagger}$ Graduate School of Pharmaceutical Sciences, Kyoto University, Yoshida, Sakyo-Ku, Kyoto 606-8501, Japan

jmaddalu@crihan.fr,tomioka@mail.pharm.kyoto-u.ac.jp 


\section{Table of contents}

$\begin{array}{ll}\text { Title and authors } & \text { S1 }\end{array}$

$\begin{array}{ll}\text { Table of contents } & \text { S2 }\end{array}$

$\begin{array}{ll}\text { Materials and methods } & \text { S2 }\end{array}$

$\begin{array}{lr}\text { Synthesis and data of the starting materials } & \text { S3 - S4 }\end{array}$

Typical procedure for the enantioselective conjugate addition of the lithium ester enolate S4

$\begin{array}{lr}\text { Experimental data for compounds 7, } 8 \text { and } \mathbf{9} & \text { S5 - S7 }\end{array}$

$\begin{array}{ll}\text { Protocol A - and - Protocol B } & \text { S8 }\end{array}$

${ }^{1} \mathrm{H}$ and ${ }^{13} \mathrm{C}$ NMR spectra for tert-butyl 4-methylpent-2-enoate S9

$\begin{array}{lr}{ }^{1} \mathrm{H} \text { and }{ }^{13} \mathrm{C} \text { NMR spectra for compounds 7, } 8 \text { and } \mathbf{9} & \mathrm{S} 10-\mathrm{S} 12\end{array}$

\section{Materials and Methods}

Tetrahydrofuran (THF), toluene and diethylether (ether) were dried from sodium/benzophenone. All reagents were of reagent grade and were used as such or distilled prior to use. Reactions were monitored by thin-layer chromatography (TLC) carried out on $0.25 \mathrm{~mm}$ E. Merck 5735 Kieselgel silica gel coated aluminium plates (60 F254) using UV light as visualizing agent and $7 \%$ ethanolic phosphomolybdic acid, aqueous $\mathrm{KMnO}_{4}$ or ninhydrin solution and heat as developing agents. E. Merck silica gel (60, particle size $0.040-0.063 \mathrm{~mm})$ was used for flash chromatography. ${ }^{1} \mathrm{H}$ and ${ }^{13} \mathrm{C} \mathrm{NMR}$ spectra were recorded at room temperature at $300 \mathrm{MHz}$ and 75 $\mathrm{MHz}$ respectively and calibrated using residual undeuterated solvent as an internal reference. The solvent was deuteriochloroform, unless otherwise noted, with a calibration at $7.26 \mathrm{ppm}$ for ${ }^{1} \mathrm{H}$ spectra and $77.16 \mathrm{ppm}$ for ${ }^{13} \mathrm{C}$ spectra. Chemical shifs $(\delta)$ are given in parts per million $(\mathrm{ppm})$ and the coupling constants $(J)$ in hertz $(\mathrm{Hz})$. The following abbreviations were used to designate the multiplicities: $\mathrm{s}=$ singlet, $\mathrm{d}=$ doublet, $\mathrm{t}=$ triplet, $\mathrm{q}=$ quartet, $\mathrm{qt}=$ quintet, $\mathrm{hp}=$ heptuplet, $\mathrm{m}=$ multiplet, $\mathrm{br}=$ broad. $\mathrm{IR}$ spectra were recorded by transmission on a IRTF spectrometer. Optical rotations were recorded at $20{ }^{\circ} \mathrm{C}$ on a polarimeter using the sodium D line (589 nm) and $[\alpha]_{\mathrm{D}}$ are given in units of $10^{-1} \mathrm{deg} \mathrm{cm}^{-2} \mathrm{~g}^{-1}$. The mass spectra were obtained under electron impact conditions (EI) at $70 \mathrm{eV}$ ionizing potential; $i$-butane $\left({ }^{\mathrm{i}} \mathrm{BuH}\right)$ was used for chemical ionization (CI). Melting points (m.p.) are uncorrected and were measured using a microscope apparatus. Elemental analyses were performed with an analyser. The reference given at the end of each protocol sends back to the previous description of the same compound. 


\section{Synthesis and data of the starting materials}

tert-Butylcinnamate. A solution of methylcinnamate $(5 \mathrm{~g}, 31 \mathrm{mmol})$ in freshly distillated ether $(30 \mathrm{~mL})$ was added to a solution of $t$-BuOK $(8.3 \mathrm{~g}, 74 \mathrm{mmol})$ in ether $(120 \mathrm{~mL})$ at $0^{\circ} \mathrm{C}$ under nitrogen. Then, the mixture was stirred at $20^{\circ} \mathrm{C}$ for $30 \mathrm{~min}$ and cold water was added until the complete dissolution of the white precipitate (MeOK). The organic layer was separated, dried $\left(\mathrm{MgSO}_{4}\right)$ and concentrated under reduce pressure. The residue was purified by distillation (bp $65^{\circ} \mathrm{C} / 1 \mathrm{mmHg}$ ) to afford the desired product $(3.59 \mathrm{~g}, 57 \%)$ as a colorless oil. (Vasin, V. A.; Razin, V. V. Synlett 2001, 5, 658-660)

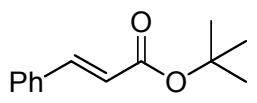

${ }^{1} \mathrm{H}$ NMR: $\delta 1.54(9 \mathrm{H}, \mathrm{s}), 6.37(1 \mathrm{H}, \mathrm{d}, J=16.0), 7.32-7.43(3 \mathrm{H}, \mathrm{m}), 7.45-7.55(2 \mathrm{H}, \mathrm{m}), 7.59(1 \mathrm{H}, \mathrm{d}, J=16.0) .{ }^{13} \mathrm{C}$ NMR: $\delta 28.3,80.6,120.3,128.1,128.9,130.1,134.8,143.7,166.5$. IR (film, NaCl): 1707, 1636, 1577, 1495, 1474, 1449, 1391, 1367, 1328, 1284, 1255, 1207, 1150. EIMS m/z 204 (M+1 15), 189 (4), 148 (100), 147 (97), 131 (48), 103 (29), 77 (16), 57 (28). Anal. Calcd. For $\mathrm{C}_{13} \mathrm{H}_{16} \mathrm{O}_{2}$ : C 76.44, H 7.90, Found: C 76.56, H 7.89.

(E) 4-Methylpenten-2-oic acid. Isobutyraldehyde $(2.3 \mathrm{~mL}, 25 \mathrm{mmol})$ was added to a solution of malonic acid $(2.1 \mathrm{~g}, 20 \mathrm{mmol})$ in pyridine $(5 \mathrm{~mL})$ at $0^{\circ} \mathrm{C}$ and the mixture was heated $5 \mathrm{~h}$ at $55^{\circ} \mathrm{C}$ then $2 \mathrm{~h}$ at $110^{\circ} \mathrm{C}$. After cooling, the pyridine was eliminated under reduce pressure and the residue was diluted in ether. A solution of $50 \%$ sulfuric acid $(3 \mathrm{~mL})$ was added at $0^{\circ} \mathrm{C}$, and the resulting solution was extracted with ether $(6 * 20 \mathrm{~mL})$. The organic layers were combined, dried $\left(\mathrm{MgSO}_{4}\right)$ and concentrated under reduce pressure. The crude product was purified by distillation $\left(\mathrm{bp} 100^{\circ} \mathrm{C} / 20 \mathrm{mmHg}\right)$ to give the desired product $(0.81 \mathrm{~g}, 35 \%)$ as a colorless oil. (Shabtai, J.; Ney-Igner, E; Pines, H. J. Org. Chem. 1981, 46, 3795-3802).

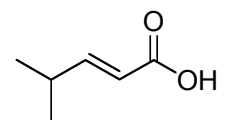

${ }^{1} \mathrm{H}$ NMR: $\delta 1.05(6 \mathrm{H}, \mathrm{d}, J=6.8), 2.46(1 \mathrm{H}, \mathrm{doc}, J=6.8,1.5), 5.76(1 \mathrm{H}, \mathrm{dd}, J=15.8,1.5), 7.05(1 \mathrm{H}, \mathrm{dd}, J=15.8$, 6.8), 12.27 (1H, s br). ${ }^{13} \mathrm{C}$ NMR: $\delta 21.2,31.2,118.2,158.5,173.0$. IR (film, NaCl): 1715, 1651, 1466, 1418, $1386,1366,1341,1284,1215,1174$.

(E) tert-Butyl 4-methylpent-2-enoate. Thionyl chloride $(9.6 \mathrm{~mL}, 132 \mathrm{mmol})$ was added to a solution of $(E)$ 4methylpent-2-enoic acid $(7.5 \mathrm{~g}, 66 \mathrm{mmol})$ in freshly distilled $\mathrm{CH}_{2} \mathrm{Cl}_{2}(75 \mathrm{~mL})$ and the mixture was stirred $2 \mathrm{~h}$ at room temperature. The excess of $\mathrm{SOCl}_{2}$ was evaporated under reduced pressure, then $\mathrm{CH}_{2} \mathrm{Cl}_{2}(20 \mathrm{~mL})$ was added and the resulting mixture was evaporated again. This procedure was repeated twice for a complete elimination of $\mathrm{SOCl}_{2}$. tert-Butanol $(31.2 \mathrm{~mL}, 330 \mathrm{mmol})$ was dropwise added to a solution of the previously formed acid chloride in $\mathrm{CH}_{2} \mathrm{Cl}_{2}(20 \mathrm{~mL})$. The mixture was stirred $3 \mathrm{~h}$ at room temperature, quenched with saturated $\mathrm{NH}_{4} \mathrm{Cl}$ and extracted with $\mathrm{CH}_{2} \mathrm{Cl}_{2}(3 * 20 \mathrm{~mL})$. The organic layers were combined, washed with saturated $\mathrm{NaHCO}_{3}$ then brine, dried $\left(\mathrm{MgSO}_{4}\right)$ and concentrated under reduce pressure. The crude product was purified by distillation (bp $\left.70{ }^{\circ} \mathrm{C} / 20 \mathrm{mmHg}\right)$ to give the desired product $(6.88 \mathrm{~g}, 62 \%)$ as a colorless oil. 


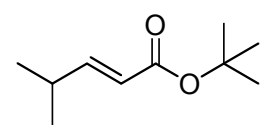

${ }^{1} \mathrm{H}$ NMR: $\delta 1.04(6 \mathrm{H}, \mathrm{d}, J=6.8), 1.48(9 \mathrm{H}, \mathrm{s}), 2.43(1 \mathrm{H}, \mathrm{ddhp}, J=6.8,6.8,1.5), 5.71(1 \mathrm{H}, \mathrm{dd}, J=15.8,1.5)$, $6.84(1 \mathrm{H}, \mathrm{dd}, J=15.8,6.8) .{ }^{13} \mathrm{C}$ NMR: $\delta 21.3,28.2,30.8,80.0,120.3,154.2,166.4$. IR (film, NaCl): 1755,1652 , 1461, 1391, 1366, 1346, 1315, 1301, 1258, 1204, 1154. EIMS m/z 170 (M+ <1), 155 (3), 115 (79), 114 (72), 97 (100), 69 (22), 57 (96).

2,4-Dimethylpentan-3-yl iso-butyrate 4 (precursor of the lithium ester enolate 1). A mixture of iso-butyric acid (9.3 mL, $100 \mathrm{mmol}), 2$, 4-dimethylpentan-3-ol (42.0 mL, $300 \mathrm{mmol})$ and para-toluenesulfonic acid monohydrate $(0.190 \mathrm{~g}, 1 \mathrm{mmol})$ in toluene $(20 \mathrm{~mL})$ was stirred at reflux for $48 \mathrm{~h}$ in a Dean-Stark apparatus. After cooling to room temperature, the medium was quenched with saturated $\mathrm{NaHCO}_{3}$. The organic layer was washed with brine, dried $\left(\mathrm{MgSO}_{4}\right)$ and concentrated under reduce pressure. The residue was purified by distillation $\left(\mathrm{bp} 80^{\circ} \mathrm{C} / 10\right.$ $\mathrm{mmHg}$ ) to afford the desired product $(8.95 \mathrm{~g}, 48 \%)$ as a colorless oil. (Kambara, T.; Tomioka, K. J. Org. Chem. 1999, 64, 9282-9285)

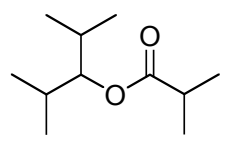

${ }^{1} \mathrm{H}$ NMR: $\delta 0.85(2 * 3 \mathrm{H}, \mathrm{d}, J=6.8), 0.87(2 * 3 \mathrm{H}, \mathrm{d}, J=6.8), 1.19(6 \mathrm{H}, \mathrm{d}, J=6.8), 1.89(2 \mathrm{H}, \mathrm{dhp}, J=6.8,6.0)$, $2.58(1 \mathrm{H}, \mathrm{hp}, J=6.8), 4.58(1 \mathrm{H}, \mathrm{t}, J=6.0) .{ }^{13} \mathrm{C} \mathrm{NMR}: \delta 17.3,19.4$ and 19.6, 29.5, 34.6, 82.0, 177.1. IR (film, $\mathrm{NaCl}): 1734,1469,1387,1369,1337,1259,1194,1160,1131,1097,1068$. EIMS m/z $186\left(\mathrm{M}^{+},<1\right), 143(12)$, 114 (2), 98 (3), 71 (100), 57 (13). Anal. calcd for $\mathrm{C}_{11} \mathrm{H}_{22} \mathrm{O}_{2}$ : C 70.92, H 11.90; found: C 70.97, H 11.95.

Typical procedure for the enantioselective conjugate addition of lithium ester enolate to $\alpha, \beta$-unsaturated esters in the presence of chiral 3APLi.
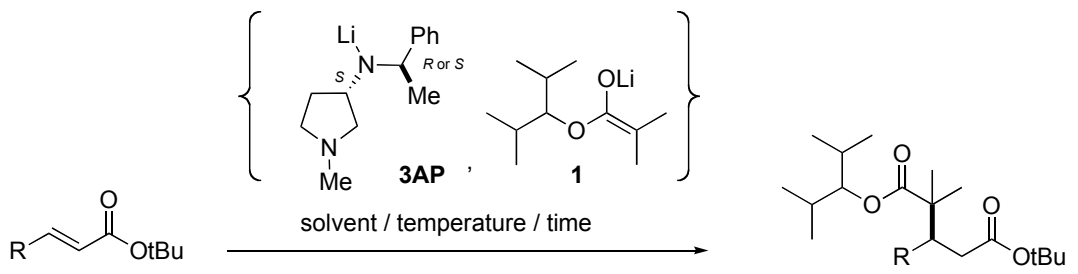

Under an argon atmosphere, $n$-BuLi $(0.85 \mathrm{mmol}, 2.5 \mathrm{M}$ solution in hexanes) was added to a solution of 3AP $(0.85 \mathrm{mmol})$ in $\mathrm{THF}(5 \mathrm{~mL})$ at $-20^{\circ} \mathrm{C}$. After stirring $20 \mathrm{~min}$, a solution of 2, 4-dimethylpentan-3-yl iso-butyrate 4 $(0.65 \mathrm{mmol})$ in THF $(4 \mathrm{~mL})$ was added dropwise to the preformed solution of 3APLi and the resulting mixture was stirred $30 \mathrm{~min}$ at $-20^{\circ} \mathrm{C}$. $n$ - $\mathrm{BuLi}(0.65 \mathrm{mmol}, 2.5 \mathrm{M}$ solution in hexanes $)$ was added at $-20^{\circ} \mathrm{C}$ and the mixture was aged $30 \mathrm{~min}$ at $-78^{\circ} \mathrm{C}$. A solution of $\alpha, \beta$-unsaturated ester $(0.5 \mathrm{mmol})$ in THF $(1 \mathrm{~mL})$ was added at $-78^{\circ} \mathrm{C}$ and the mixture was stirred at $-78^{\circ} \mathrm{C}$ for the indicated time. The reaction was quenched with saturated $\mathrm{NH}_{4} \mathrm{Cl}$ and $3 \mathrm{M} \mathrm{HCl}(2 \mathrm{~mL})$ and was extracted with ether $(3 * 15 \mathrm{~mL})$ after reaching room temperature. The combined organic layers were washed with $\mathrm{NaHCO}_{3}(15 \mathrm{~mL})$ and brine $(15 \mathrm{~mL})$, dried $\left(\mathrm{MgSO}_{4}\right)$ and concentrated under reduce pressure. The residue was purified by silica gel column chromatography to give the corresponding Michael adducts. 


\section{5 - Ter $t$ - b u t y l 1 - ( 2, 4 - d i m e t h y l pe n t a n - 3 - y l ) 2,2,3 - trimethylpentanedioate 7.}

$\alpha, \beta$-Unsaturated ester was $(E)$ tert-butyl crotonate. Purification by flash chromatography on silica gel (cyclohexane/ether 95:5) gave 7 as a colorless oil.

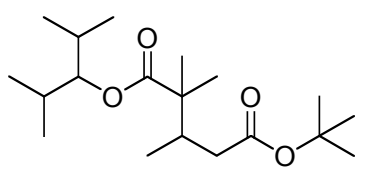

${ }^{1} \mathrm{H}$ NMR: $\delta 0.81(2 * 3 \mathrm{H}, \mathrm{d}, J=6.8), 0.83(2 * 3 \mathrm{H}, \mathrm{d}, J=6.8), 0.87(3 \mathrm{H}, \mathrm{d}, J=6.8), 1.07$ (3H, s), 1.09 (3H, s), $1.38(9 \mathrm{H}, \mathrm{s}), 1.86(2 \mathrm{H}, \mathrm{dhp}, J=6.8,6.0), 1.91(1 \mathrm{H}, \mathrm{dd}, J=14.9,10.6), 2.30(1 \mathrm{H}, \mathrm{dd}, J=14.9,10.6), 2.33(1 \mathrm{H}$, ddq, $J=10.6,6.8,3.0), 4.55(1 \mathrm{H}, \mathrm{t}, J=6.0) .{ }^{13} \mathrm{C} \mathrm{NMR}: \delta 15.0,17.4$ and $17.5,19.9,21.9,22.7,28.1,29.6$ and 29.7, 36.7, 38.9, 46.1, 80.2, 82.6, 172.5, 177.4. IR (film, NaCl): 1716, 1471, 1391, 1368, 1305, 1263, 1158, 1142, 1126, $1097 \mathrm{~cm}^{-1}$. EIMS m/z $328\left(\mathrm{M}^{+},<1\right), 273$ (2), 213 (7), 186 (8), 174 (5), 157 (100), 129 (63), 115 (5), 111 (22), 99 (14), 88, (18), 70 (27), 57 (81). Anal. calcd for $\mathrm{C}_{19} \mathrm{H}_{36} \mathrm{O}_{4}$ : C 69.47, H 11.05; found: C 69.59, H 10.98. $[\alpha]^{20}{ }_{D}+4.40\left(c 1.64, \mathrm{CHCl}_{3}\right)$ when $76 \%$ ee.

HPLC 76\% ee (Daicel Chiralpak AD-H, hexane/i-Pr 1000:1, $0.5 \mathrm{~mL} / \mathrm{min}, 230 \mathrm{~nm}$, major $16.4 \mathrm{~min}$ and minor $18.6 \mathrm{~min}$ )

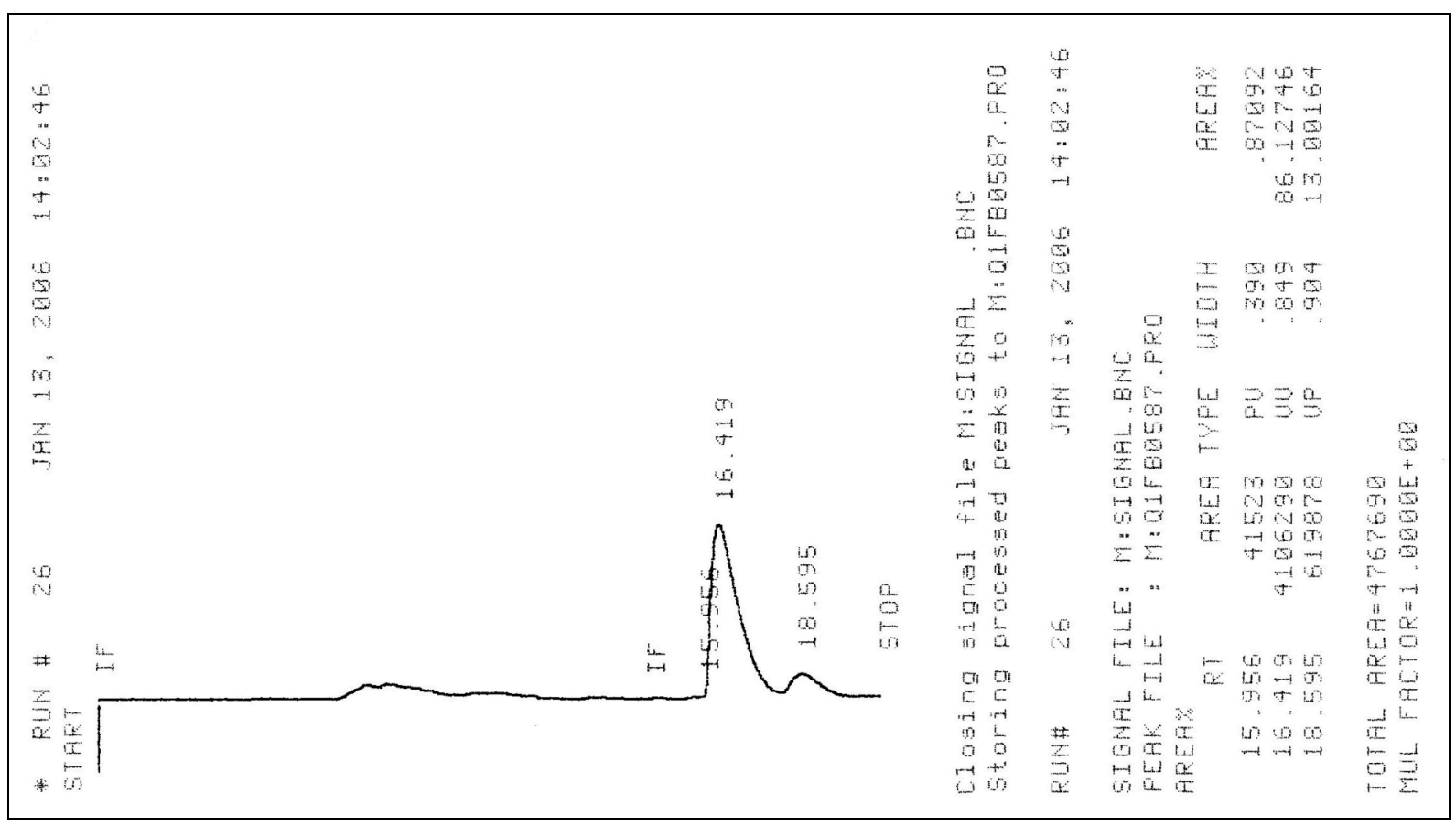




\section{5 - T e r t - b u t y l 1 - ( 2,4 - d i m e t h y l p e n t a n - 3 - y l ) 2 , 2 - dimethyl-3-phenylpentanedioate 8.}

$\alpha, \beta$-Unsaturated ester was $(E)$ tert-butyl cinnamate. Purification by flash chromatography on silica gel (cyclohexane/ether 95:5) gave 8 as a white solid.

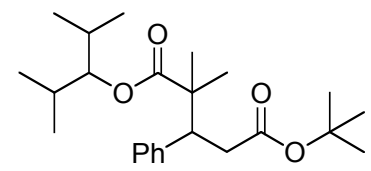

m.p. $=82^{\circ} \mathrm{C}$ (cyclohexane) .

${ }^{1} \mathrm{H}$ NMR: $\delta$ 0.82-0.95 (12H, d, $\left.J=6.4\right), 1.09(3 \mathrm{H}, \mathrm{s}), 1.16(9 \mathrm{H}, \mathrm{s}), 1.18,(3 \mathrm{H}, \mathrm{s}), 1.94(2 \mathrm{H}, \mathrm{dhp}, J=6.4,6.0), 2.61$ $(1 \mathrm{H}, \mathrm{dd}, J=15.1,3.8), 2.79(1 \mathrm{H}, \mathrm{dd}, J=15.1,12.4), 3.62(1 \mathrm{H}, \mathrm{dd}, J=12.4,3.8), 4.65(1 \mathrm{H}, \mathrm{t}, J=6.0), 7.15-7.35$ (5H, m). ${ }^{13} \mathrm{C}$ NMR: $\delta 17.4$ and 17.6, 19.8 and 19.9, 20.4, 25.9, 27.7, 29.5 and 29.7, 37.5, 46.2, 48.7, 80.2, 82.9, 126.9, 127.8, 130.2, 139.2, 171.2, 177.2. IR (film, NaCl): 1716, 1602, 1494, 1470, 1454, 1390, 1367, 1345, 1303, 1255, 1216, 1150. EIMS m/z $391\left(\mathrm{M}^{+},<1\right), 334$ (15), 275 (4), 236 (32), 219 (94), 190 (31), 149 (85), 131 (19), 117 (10), 107 (33), 99 (21), 88, (55), 70 (16), 57 (100). Anal. calcd for $\mathrm{C}_{24} \mathrm{H}_{38} \mathrm{O}_{4}$ : C 73.81, H 9.81; found: C 73.79, H 9.73.

$[\alpha]^{20}{ }_{D}-7.30\left(c 0.65, \mathrm{CHCl}_{3}\right)$ when $50 \%$ ee.

HPLC 50\% ee (Daicel Chiralpak AD-H, hexane/i-Pr 500:1, $0.5 \mathrm{~mL} / \mathrm{min}, 254 \mathrm{~nm}$, major $25.5 \mathrm{~min}$ and minor 44.9 $\min$ )

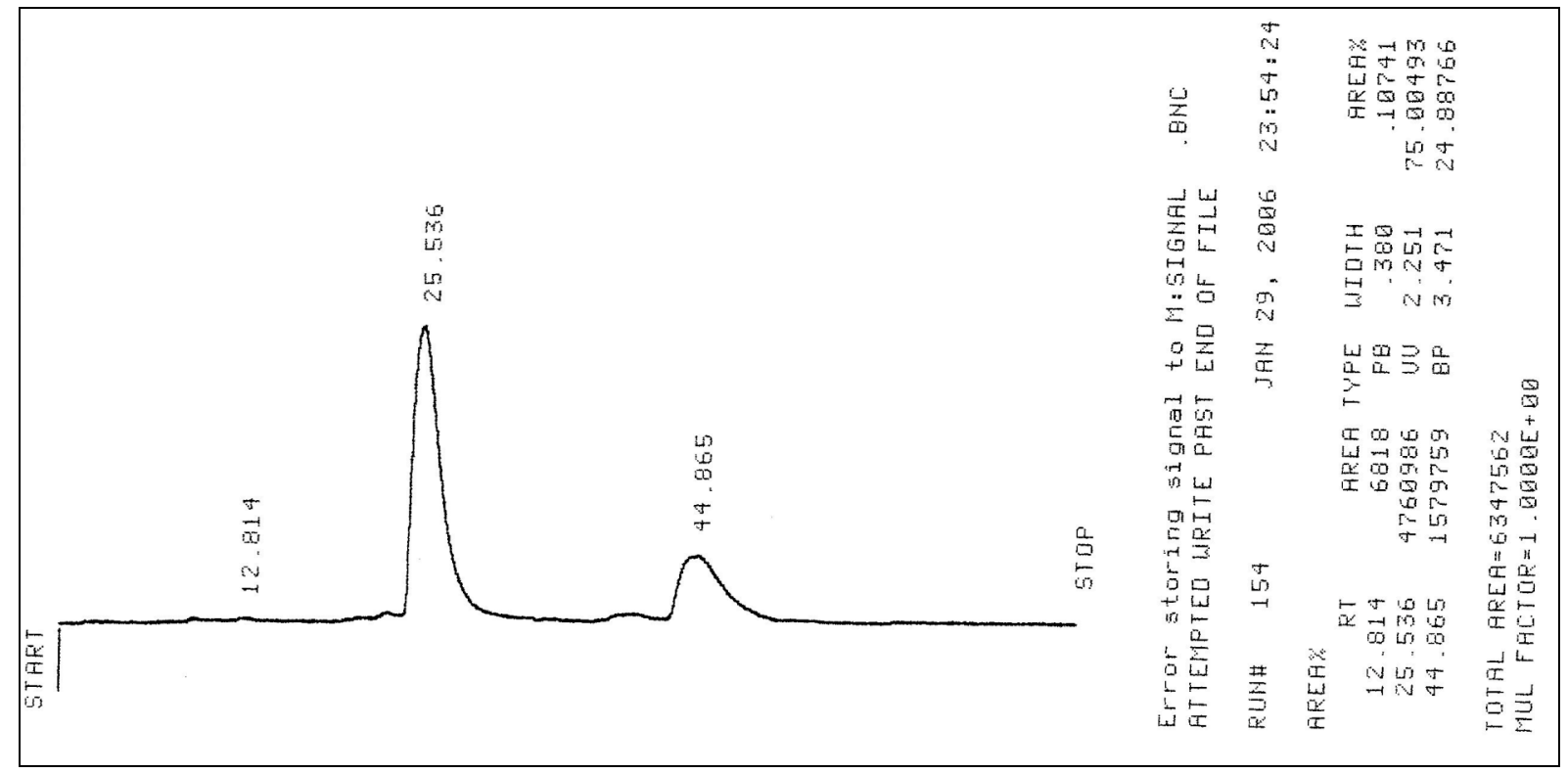




\section{5-Tert-butyl 1-(2,4-dimethylpentan-3-yl) 3-iso-propyl-2,2-dimethylpentanedioate 9.}

$\alpha, \beta$-Unsaturated ester was (E) tert-butyl 4-methylpent-2-enoate. Purification by flash chromatography on silica gel (cyclohexane/ether 95:5) gave 9 as a colorless oil.

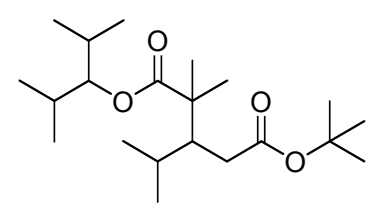

${ }^{1} \mathrm{H}$ NMR: $\delta 0.82(3 \mathrm{H}, \mathrm{d}, J=6.8), 0.83-0.89$ (4 *3H, d, $\left.J=6.8\right), 0.92(3 \mathrm{H}, \mathrm{d}, J=6.8), 1.13(3 \mathrm{H}, \mathrm{s}), 1.14,(3 \mathrm{H}, \mathrm{s})$, $1.41(9 \mathrm{H}, \mathrm{s}), 1.78(1 \mathrm{H}, \mathrm{dhp}, J=6.8,1.9), 1.88(2 \mathrm{H}, \mathrm{dhp}, J=6.8,6.0), 2.13(1 \mathrm{H}, \mathrm{dd}, J=16.2,6.0), 2.19(1 \mathrm{H}, \mathrm{dd}$, $J=16.2,6.0), 2.39(1 \mathrm{H}, \mathrm{dt}, J=6.0,1.9), 4.57(1 \mathrm{H}, \mathrm{t}, J=6.0) .{ }^{13} \mathrm{C}$ NMR: $\delta 17.4$ and 17.7, 18.6, 19.8 and 19.9, 22.0, 24.6, 25.3, 28.1, 28.9, 29.7 and 29.8, 32.5, 46.1, 48.0, 80.1, 82.8, 173.7, 177.8. IR (film, NaCl): 1728, 1724, 1529, 1471, 1422, 1390, 1367, 1335, 1303, 1250, 1154, 1098. EIMS m/z 357 ( $\left.\mathrm{M}^{+},<1\right), 241$ (4), 202 (10), 185 (81), 169 (1), 157 (87), 139 (16), 115 (29), 99 (40), 88, (71), 70 (17), 57 (100). Anal. calcd for $\mathrm{C}_{21} \mathrm{H}_{40} \mathrm{O}_{4}: \mathrm{C} 70.74$, H 11.31; found: C 70.72, H 11.30.

$[\alpha]_{\mathrm{D}}{ }^{20}:+1.1\left(c 0.58, \mathrm{CHCl}_{3}\right)$ when $15 \%$ ee.

HPLC 15\% ee (Daicel Chiralpak AD-H, hexane/i-PrOH 500:1, 0.3 mL/min, $230 \mathrm{~nm}$, major 23.5 min and minor $26.9 \mathrm{~min}$ )

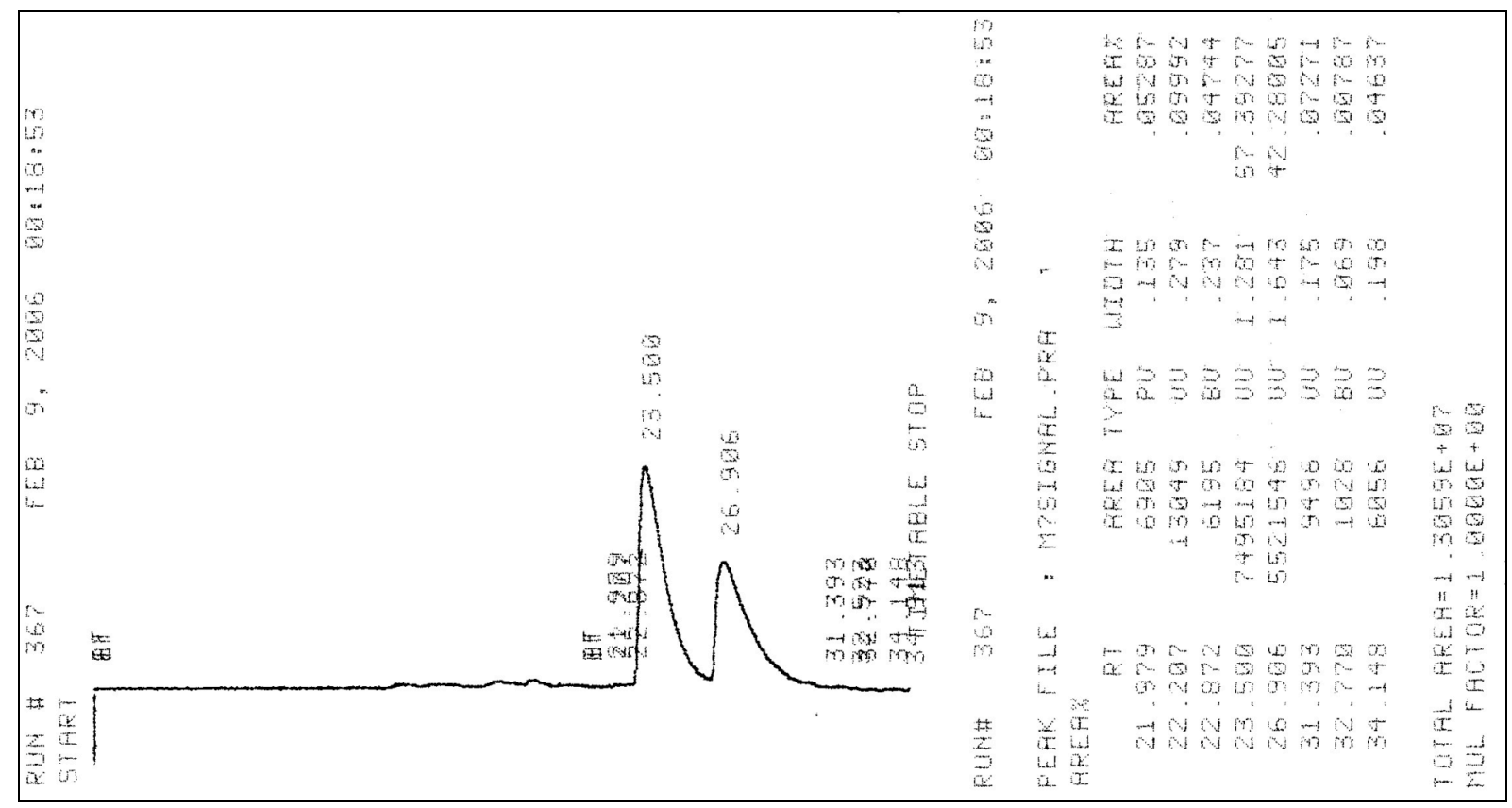


Protocol A for the conjuguate addition of the lithium enolate of 2, 4-dimethylpentan-3-yl iso-butyrate on tert-butyl crotonate in the presence of amide and amine. Under argon atmosphere, $n$-BuLi $(0.65 \mathrm{mmol}, 2.5 \mathrm{M}$ solution in hexanes) was added to a solution of the first amine $(0.65 \mathrm{mmol})$ in $\mathrm{THF}(5 \mathrm{~mL})$ at $-20^{\circ} \mathrm{C}$. After stirring $20 \mathrm{~min}$, a solution of 2,4-dimethylpentan-3-yl iso-butyrate $(0.65 \mathrm{mmol})$ in THF (4 mL) was added dropwise to the resulting amide and the mixture was stirred $30 \mathrm{~min}$ at $-20^{\circ} \mathrm{C}$. $n$ - $\mathrm{BuLi}(0.65 \mathrm{mmol}, 2.5 \mathrm{M}$ solution in hexanes) was added at $-20^{\circ} \mathrm{C}$ and the mixture was aged $30 \mathrm{~min}$ at $-78^{\circ} \mathrm{C}$. Then, a solution of the other amine $(0.65 \mathrm{mmol})$ in THF $(2 \mathrm{~mL})$ was added at $-78^{\circ} \mathrm{C}$ and the mixture was aged for another $30 \mathrm{~min}$ at $-78^{\circ} \mathrm{C}$. A solution of tert-butyl crotonate $(0.5 \mathrm{mmol})$ in $\mathrm{THF}(1 \mathrm{~mL})$ was added at $-78^{\circ} \mathrm{C}$ and the mixture was stirred at $78^{\circ} \mathrm{C}$ for $1 \mathrm{~h}$. The reaction was quenched with saturated $\mathrm{NH}_{4} \mathrm{Cl}$ and $3 \mathrm{M} \mathrm{HCl}(2 \mathrm{~mL})$ and was extracted with ether $(3 * 15 \mathrm{~mL})$ after reaching room temperature. The combined organic layers were washed with $\mathrm{NaHCO}_{3}(15 \mathrm{~mL})$ and brine $(15 \mathrm{~mL})$, dried $\left(\mathrm{MgSO}_{4}\right)$ and concentrated under reduce pressure. The residue was purified by silica gel column chromatography (cyclohexane/ether 95:5) to give the corresponding Michael adduct 7.

Protocol B for the conjuguate addition of the lithium enolate of , 4-dimethylpentan-3-yl iso-butyrate on tert-butyl crotonate in the presence of amide and amine. Under argon atmosphere, $n$-BuLi $(0.65 \mathrm{mmol}, 2.5 \mathrm{M}$ solution in hexanes) was added to a solution of amine $(0.65 \mathrm{mmol})$ in THF $(5 \mathrm{~mL})$ at $-20^{\circ} \mathrm{C}$. After stirring for 20 min, a solution of 2,4-dimethylpentan-3-yl iso-butyrate $(0.65 \mathrm{mmol})$ in THF $(4 \mathrm{~mL})$ was added dropwise to the resulting amide and the mixture was stirred $30 \mathrm{~min}$ at $-20^{\circ} \mathrm{C}$. Then, a solution of the other lithium amine $(0.65$ mmol) in THF $(2 \mathrm{~mL})$ was added at $-20^{\circ} \mathrm{C}$ and the mixture was aged for $30 \mathrm{~min}$ at $-78^{\circ} \mathrm{C}$. A solution of tertbutylcrotonate $(0.5 \mathrm{mmol})$ in THF $(1 \mathrm{~mL})$ was added at $-78^{\circ} \mathrm{C}$ and the mixture was stirred at $-78^{\circ} \mathrm{C}$ for $1 \mathrm{~h}$. The reaction was quenched with saturated $\mathrm{NH}_{4} \mathrm{Cl}$ and $3 \mathrm{M} \mathrm{HCl}(2 \mathrm{~mL})$ and was extracted with ether $(3 * 15 \mathrm{~mL})$ after reaching room temperature. The combined organic layers were washed with $\mathrm{NaHCO}_{3}(15 \mathrm{~mL})$ and brine $(15$ $\mathrm{mL})$, dried $\left(\mathrm{MgSO}_{4}\right)$ and concentrated under reduce pressure. The residue was purified by silica gel column chromatography (cyclohexane/ether 95:5) to give the corresponding Michael adduct 7. 
${ }^{1} \mathrm{H}$ and ${ }^{13} \mathrm{C}$ NMR spectra for $(E)$ tert-butyl 4-methylpent-2-enoate

${ }^{1} \mathrm{H} \mathrm{NMR}\left(\mathrm{CDCl}_{3}, 300 \mathrm{MHz}\right)$

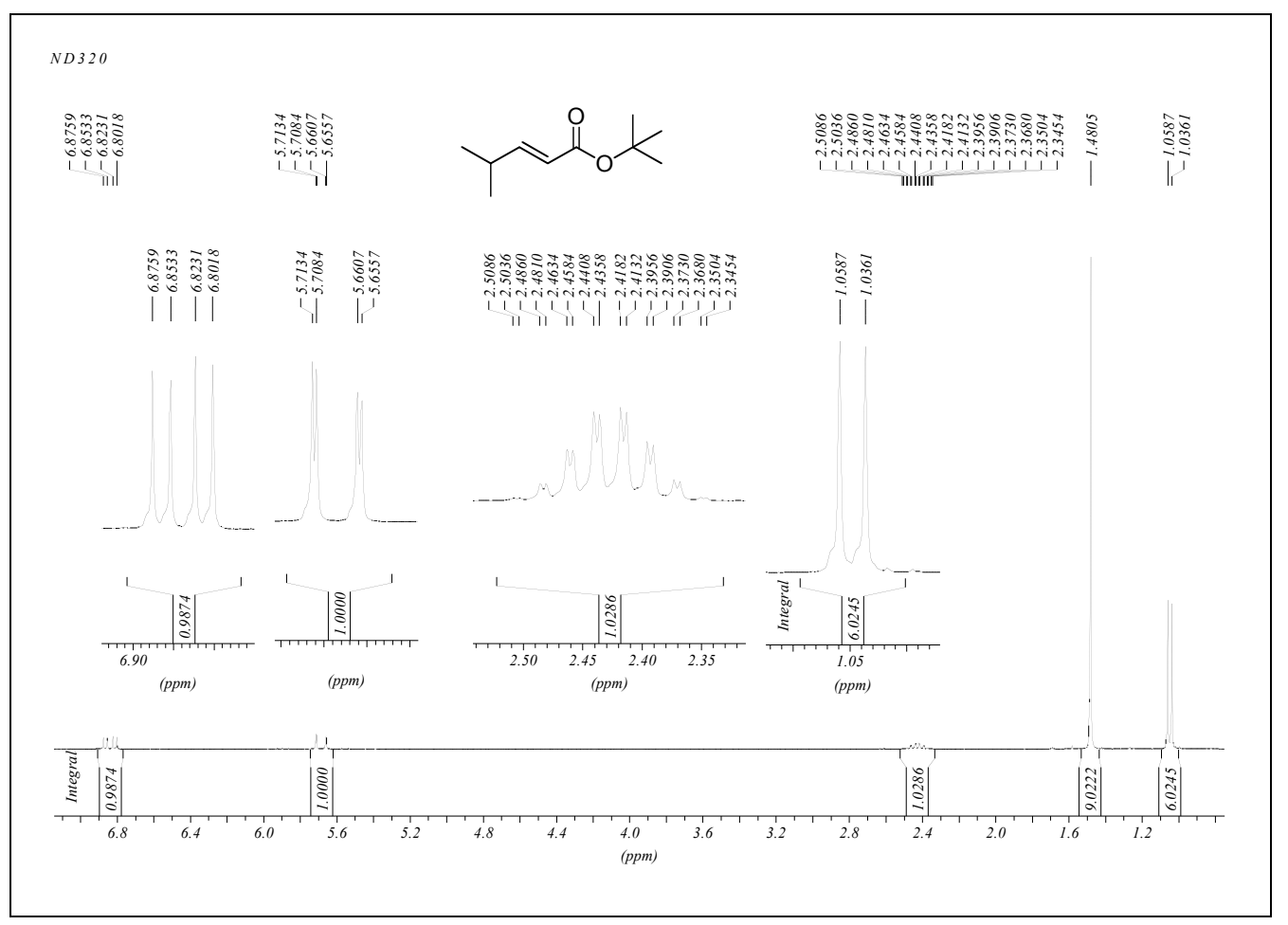

${ }^{13} \mathrm{C} \mathrm{NMR}\left(\mathrm{CDCl}_{3}, 75 \mathrm{MHz}\right)$

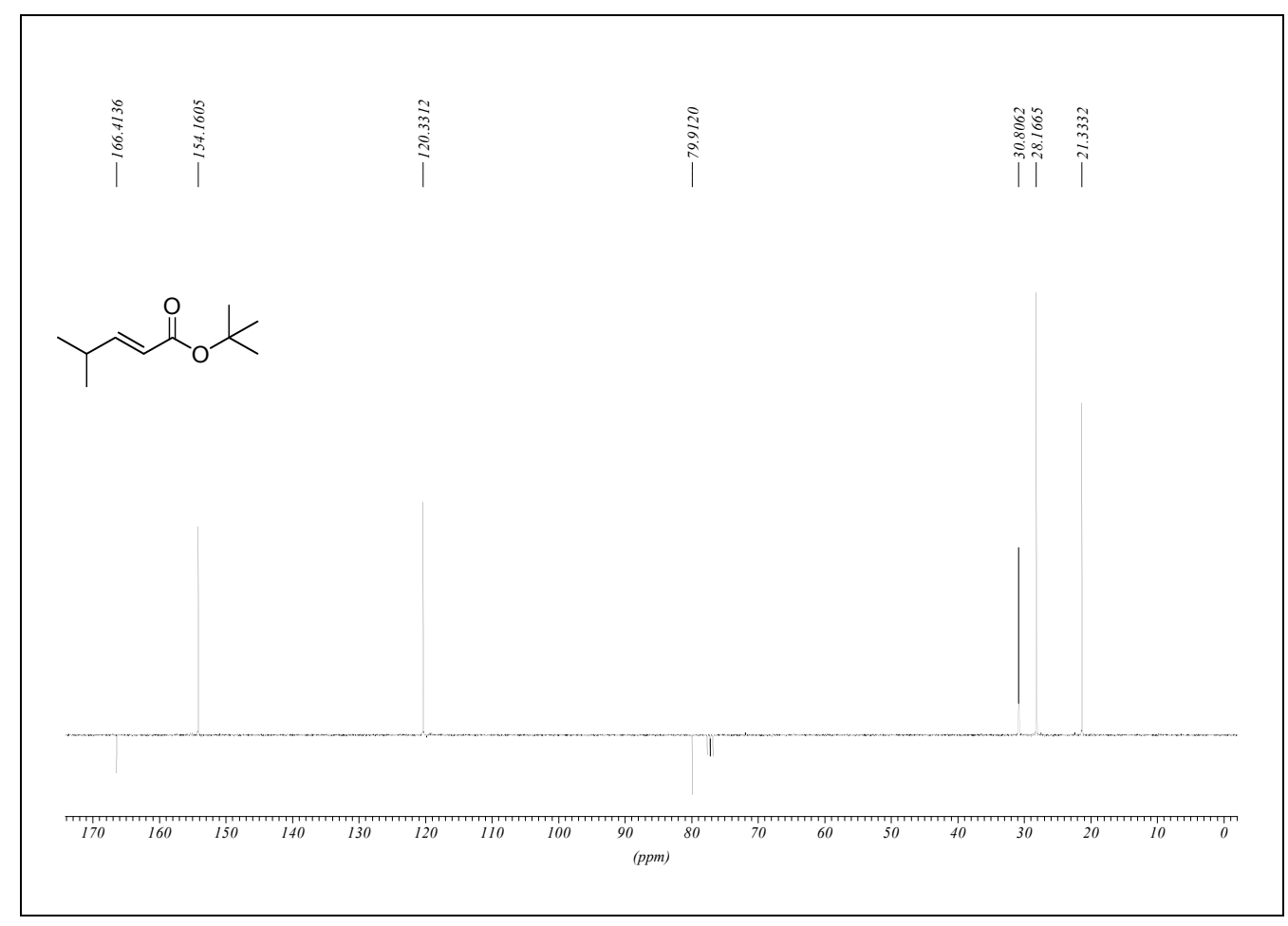

Sq 


\section{${ }^{1} \mathrm{H}$ and ${ }^{13} \mathrm{C}$ NMR spectra for 7,8 and 9}

5 - Tert-b u t y l 1 - ( 2, 4 - d i m e t h y l pe n t a n - 3 - y l ) 2,2,3-trimethylpentanedioate 7 ${ }^{1} \mathrm{H} \mathrm{NMR}\left(\mathrm{CDCl}_{3}, 300 \mathrm{MHz}\right)$

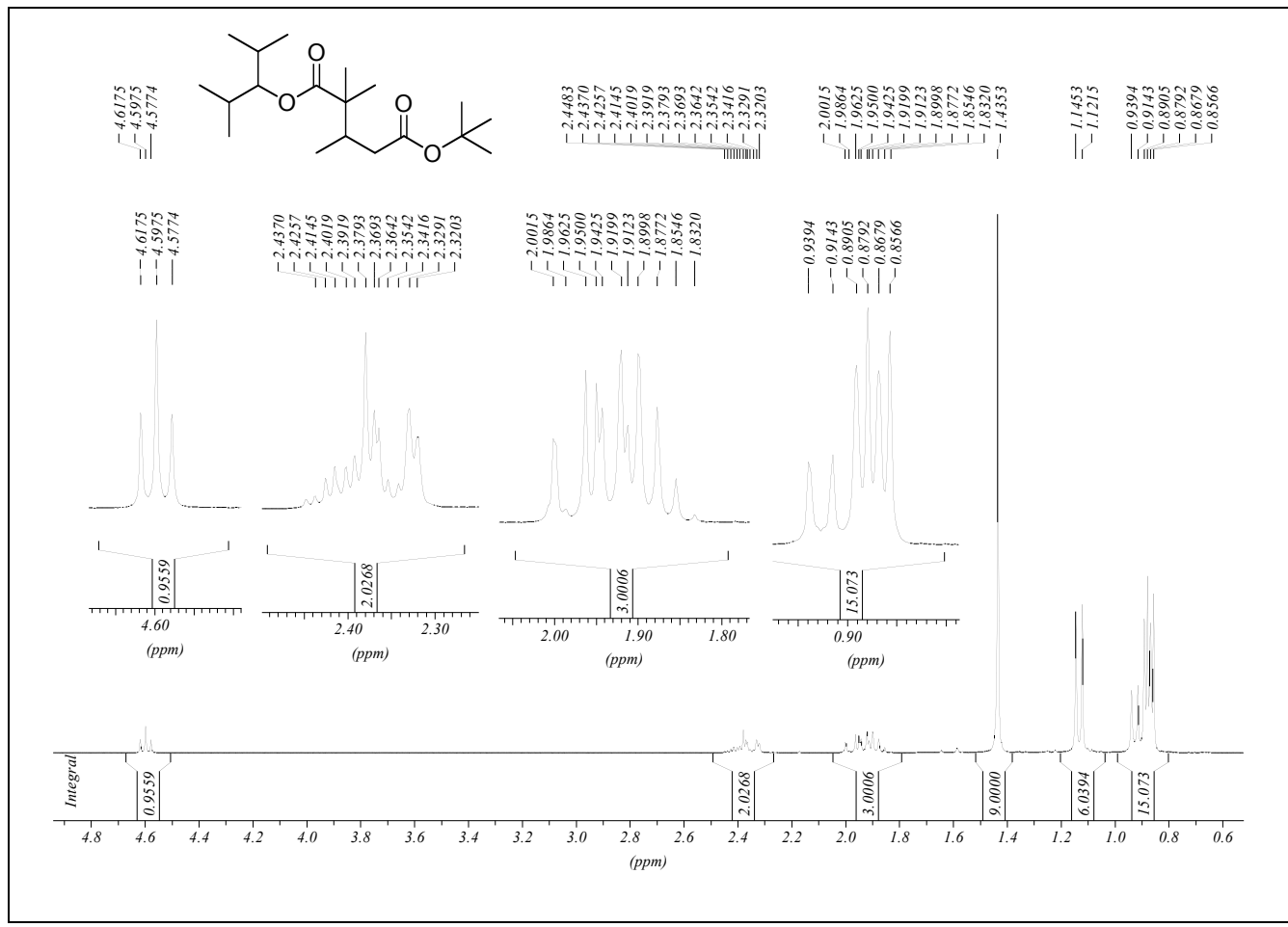

${ }^{13} \mathrm{C} \mathrm{NMR}\left(\mathrm{CDCl}_{3}, 75 \mathrm{MHz}\right)$.

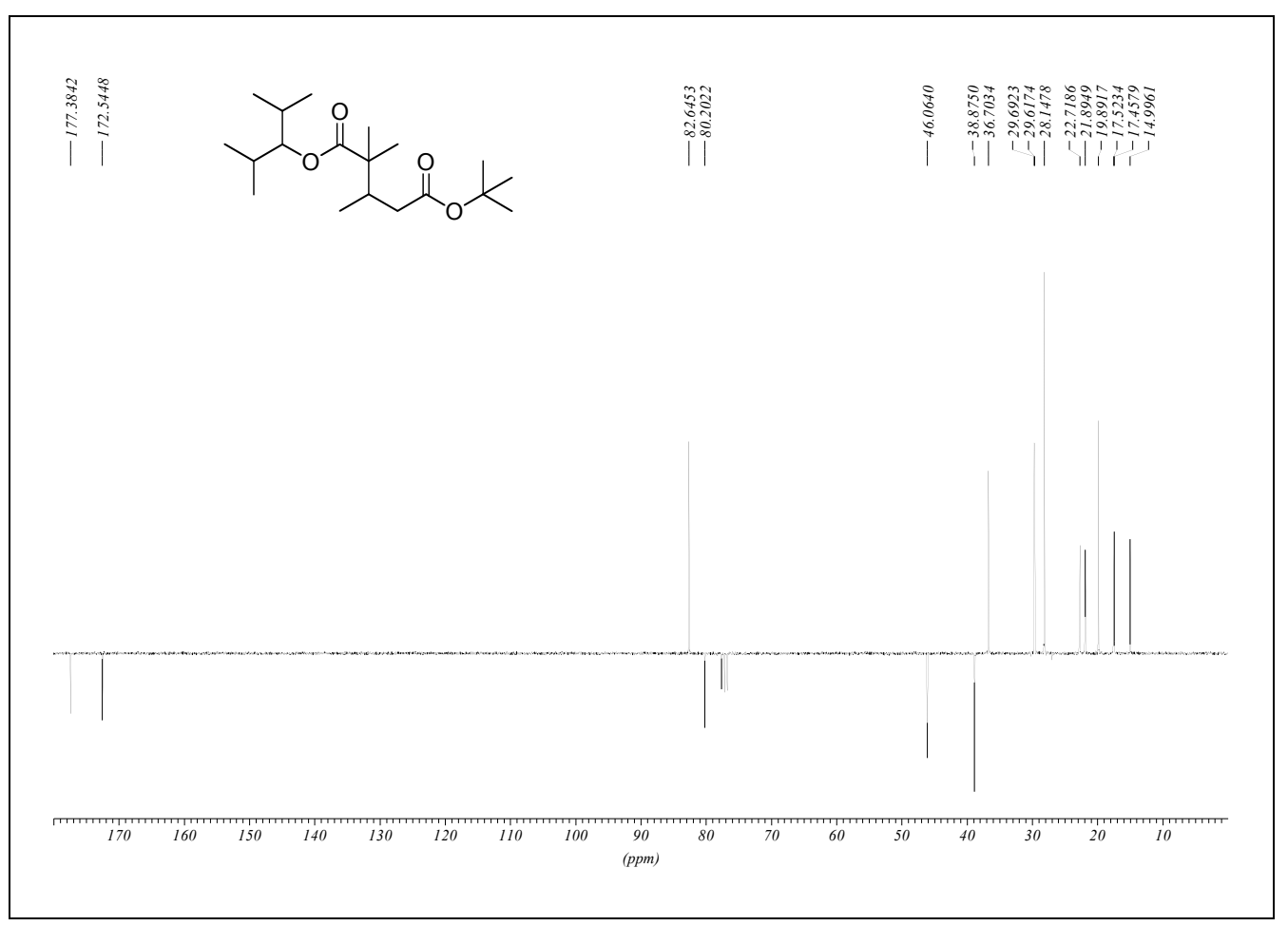


5 - $T$ e r $t$ - b u t y l 1 - ( 2,4 - d i m e t h y l pe n t a n - 3 - y l ) 2 , 2 - dimethyl-3-phenylpentanedioate 8

${ }^{1} \mathrm{H} \mathrm{NMR}\left(\mathrm{CDCl}_{3}, 300 \mathrm{MHz}\right)$

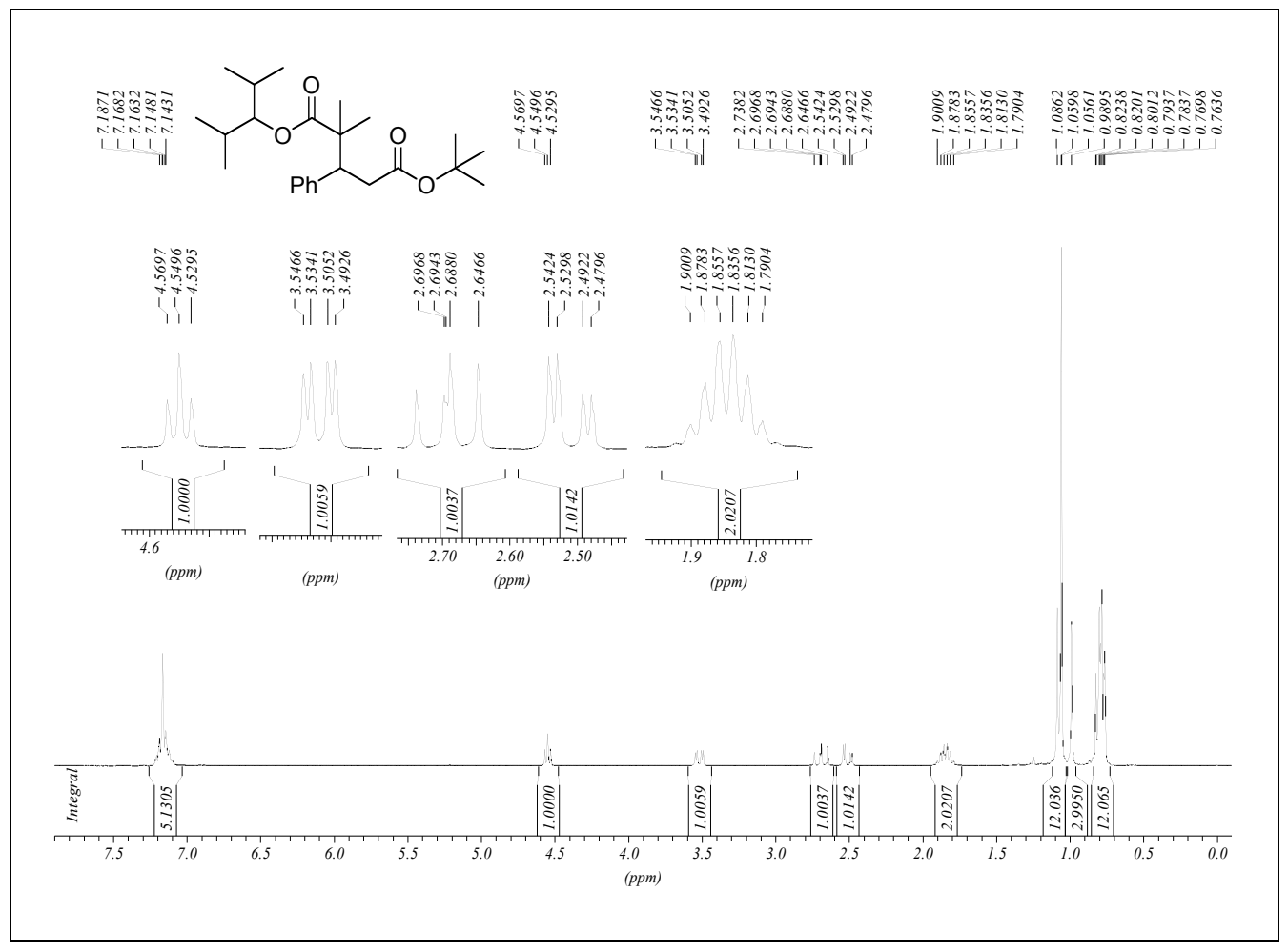

${ }^{13} \mathrm{C} \mathrm{NMR}\left(\mathrm{CDCl}_{3}, 75 \mathrm{MHz}\right)$.

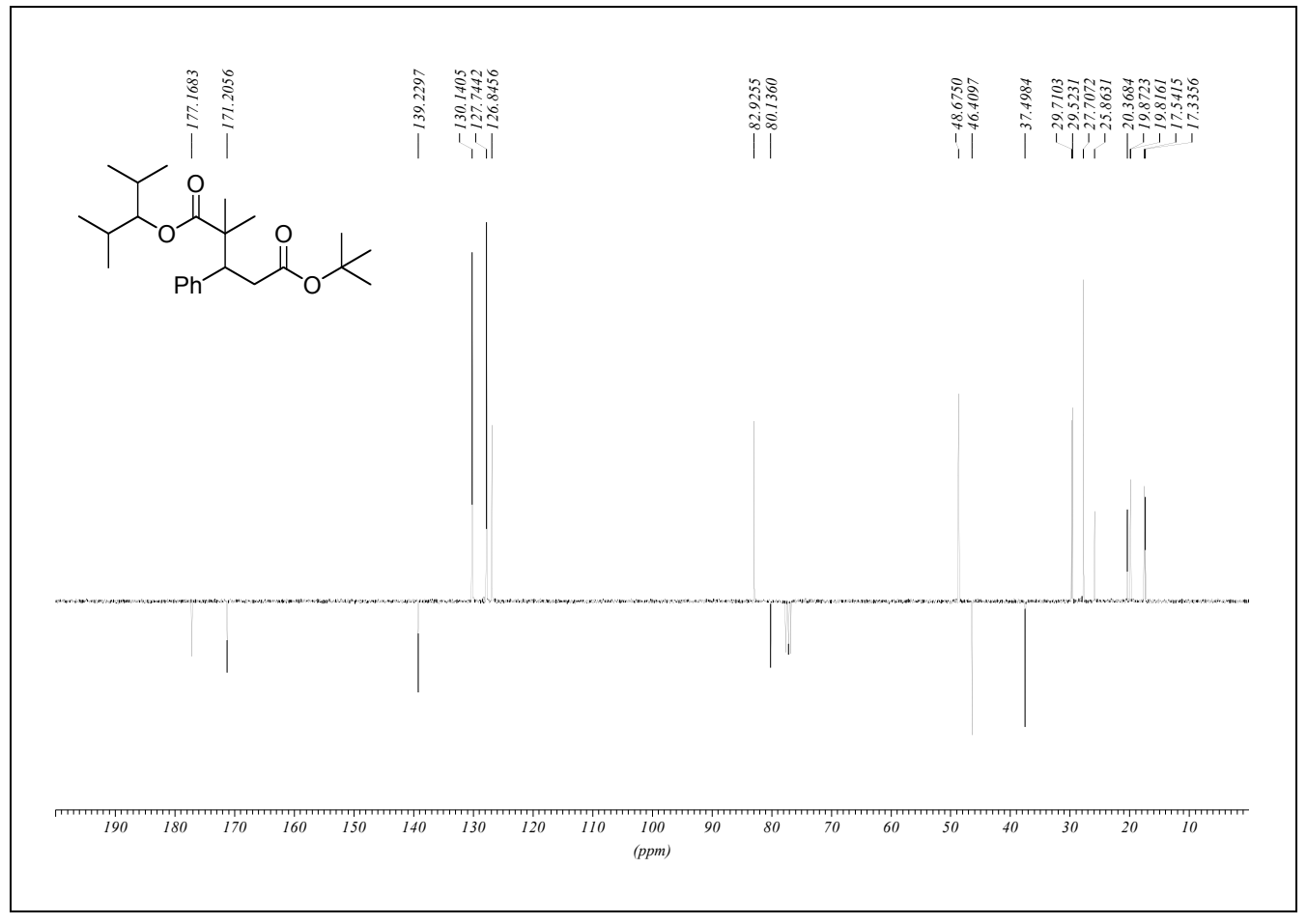


5-Tert-butyl 1-(2,4-dimethylpentan-3-yl) 3-iso-propyl-2,2-dimethylpentanedioate 9

${ }^{1} \mathrm{H} \mathrm{NMR}\left(\mathrm{CDCl}_{3}, 300 \mathrm{MHz}\right)$

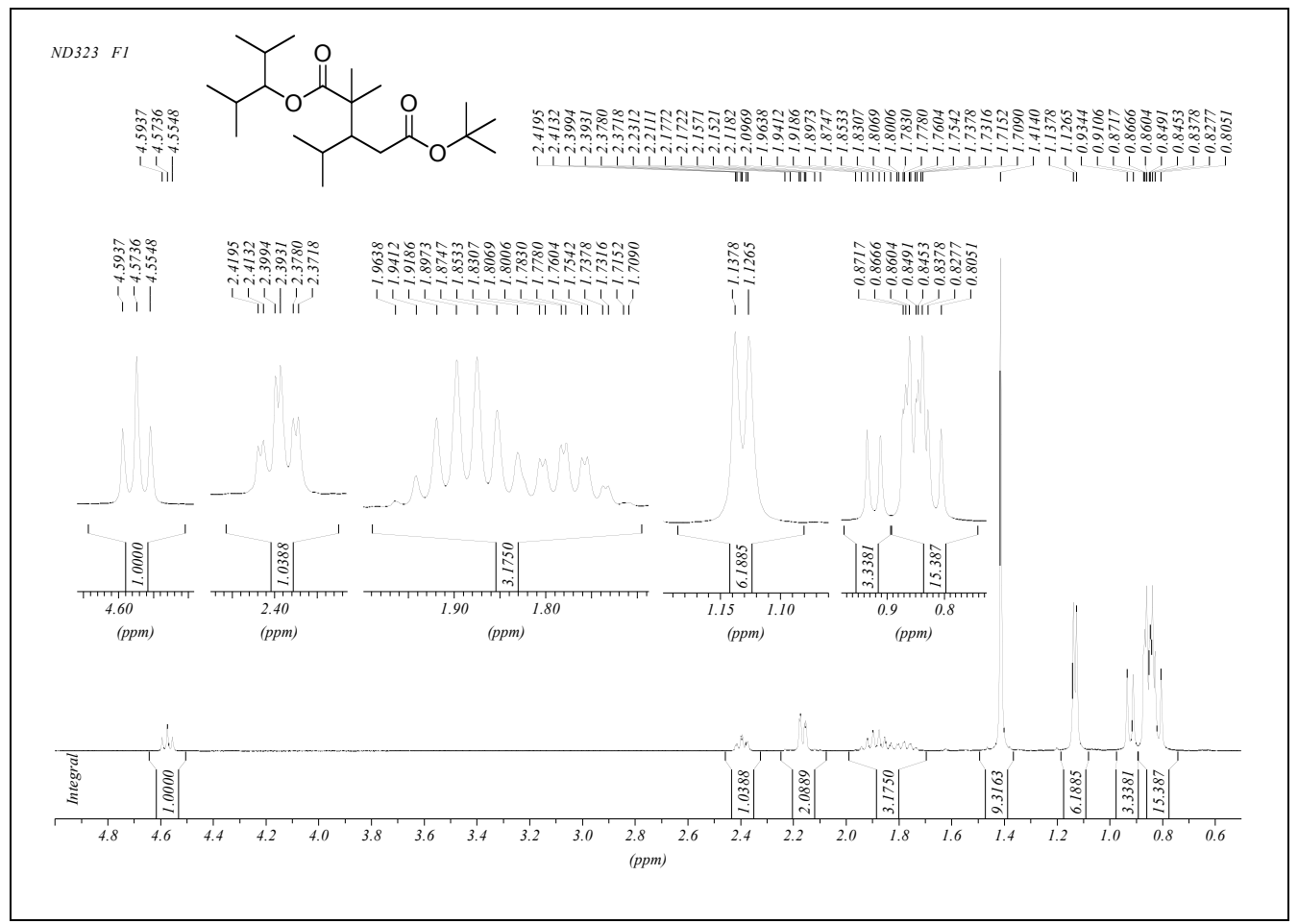

${ }^{13} \mathrm{C} \mathrm{NMR}\left(\mathrm{CDCl}_{3}, 75 \mathrm{MHz}\right)$.

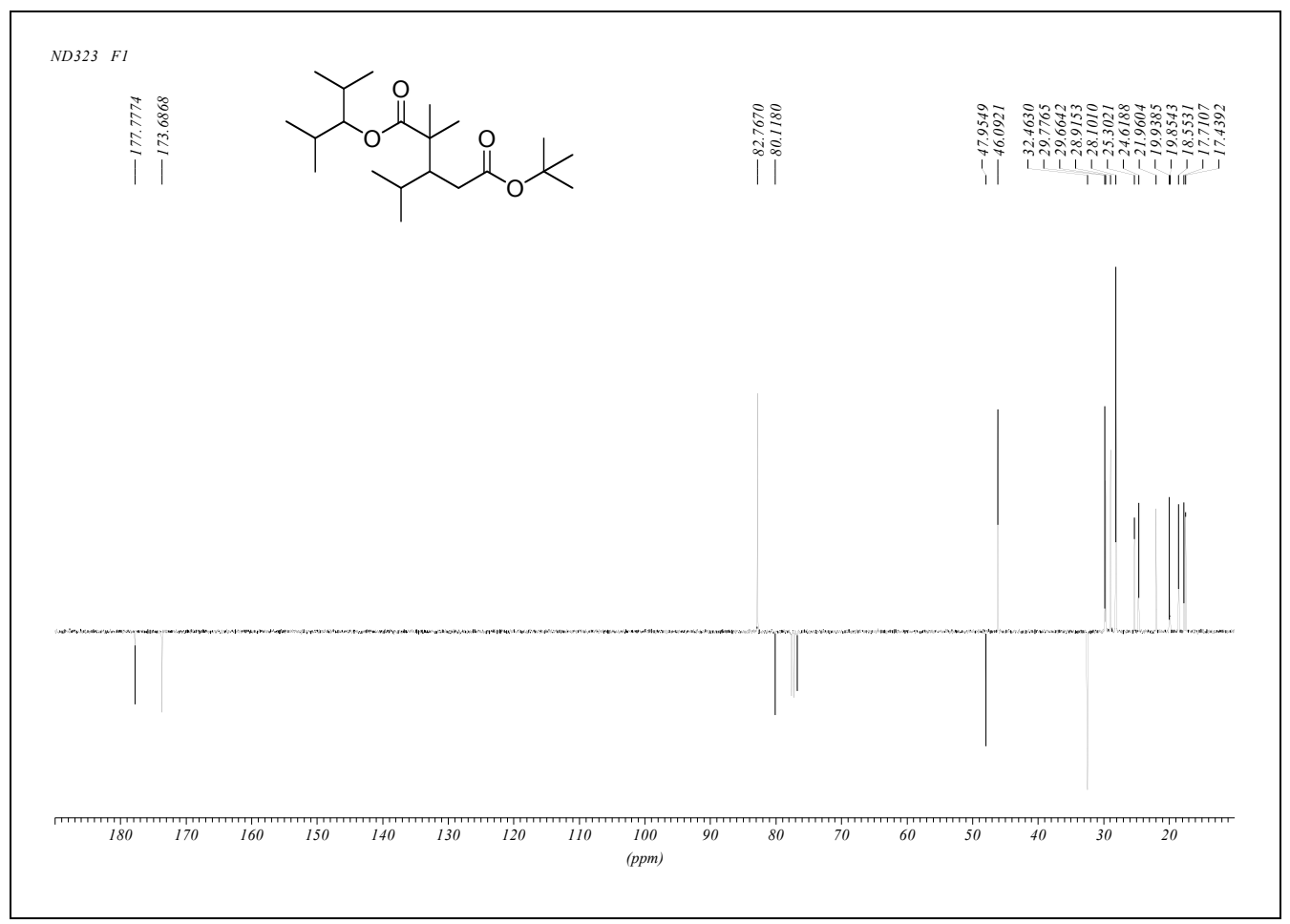

